\title{
Inhalts-Übersicht.
}

Seite

A. Begriffliches und gesetzmäßige Herstellung von $M$ ünzen und Papiergeld

l. Geldverkehr und Münzhoheit . . . . . . . . 1

II. Uber Münzen . . . . . . . . . . . . . . 2

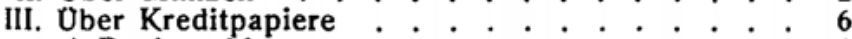

a) Papiergeld . . . . . . . . . . . . 6

b) Herstellung der Staats- und Banknoten $: .8^{\circ}$

B. Arten und strafgesetzliche Qualifikation der Fälschungen . . . . . . . . . . . . 14

l. In Beziehung auf Münzen . . . . . . . . . . 14

a) Münzfälschung . . . . . . . . . . . . . . 14

b) Münzverfälschung . . . . . . . . . . . . . 15

c) Münzbetrug . . . . . . . . . . 15

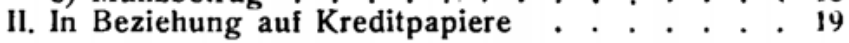

C. Wie Falsifikate entstehen . . . . . . . . 21

I. Falschmünzer . . . . . . . . . . . . . 21

1. Vergoldung und Versilberung . . . . . . . . 21

2. Ausbohrung . . . . . . . . . . . . . . 23

3. Kippen und Wippen .

4. Auflötung . . . . . . . . . . . . . . . 24

5. Prägung . . . . . . . . . . . . . . . . . 24

6. $\mathrm{Gu}$. . . . . . . . . . . . . . 26

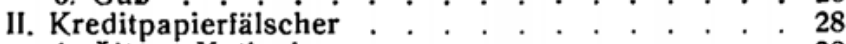

1. Altere Methoden . . . . . . . . . . . . . . 28

2. Neuere Methoden . . . . . . . . . . . . 28

3. Neueste Methoden . . . . . . . . . . . 29

D. Merkmale der Falsifikate . . . . . . . . 31

I. Metallgeldfalsa . . . . . . . . . . . . . 31

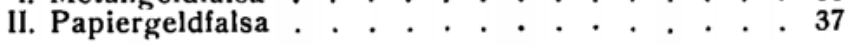

E. Ermittlung des Täters . . . . . . . . 39

I. Evidenthaltung, Nachrichtendienst, Fahndungstätigkeit . . . . . . . . . . . . . 39

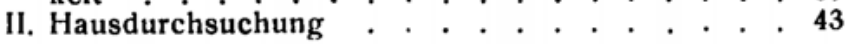





\section{Münzverbrechen und ihre Bekämpfung.}

\section{A. Begriffliches und gesetzmäßige Herstellung von Münzen und Papiergeld.}

$M$ ünzverbrecher nennt man diejenigen Individuen, welche betrügerischerweise das in den Geldverkehr und in die Münzhoheit des Staates gesetzte öffentliche Vertrauen beeinträchtigen. Münzdelikte können sowohl Metall- als auch Papiergeld zum Gegenstande haben.

\section{Geldverkehr und Münzhoheit.}

Jede menschliche Gemeinschaft, und wäre sie noch so klein, ist auf gegenseitigen Güteraustausch angewiesen. $\mathrm{Da}$ man aber nicht immer überflüssige eigene Güter hat, um dieselben gegen die im fremden Besitze befindlichen auszutauschen, da sich ferner die vorhandenen Güter nicht immer entsprechend teilen lassen, so wurden durch Sitte und Gewohnheit schon in den frühesten Zeiten die jeweilig umlauffähigsten Güter als allgemeines Tausch- und Zahlungsmittel anerkannt. Bei minder entwickeltem Verkehre erlangten auf diese Weise z. B. Perlen, Tierzähne und andere dem Putze dienende Gegenstände den Charakter von S ch muckgeld; Getreide, Früchte, Vieh, Sklaven u. dgl. den von $\mathrm{N}$ aturalge ld; Stoffe, die zum Schmucke oder zur Bekleidung dienen, den von Kleidergeld. Bei fortschreitender Kultur wurden diese Geldarten durch Metalle verdrängt, die entweder durch ihren Nutzwert (Eisen, Kupfer, Bronze) oder durch ihre Seltenheit und Haltbarkeit (Gold, Silber usw.) die allgemeinste Anerkennung errangen. Im Anfange wurden die Metall- 